\title{
DESAIN PENGEMBANGAN MODEL PEMBELAJARAN FISIKA BERBASIS MASALAH TERHADAP KETERAMPILAN BERPIKIR KRITIS DAN PROSES SAINS MAHASISWA
}

\author{
Mariati Purnama Simanjuntak, Betty Marisi Turnip dan Rappel Situmorang \\ Jurusan Fisika FMIPA Universitas Negeri Medan \\ mariati_ps@yahoo.co.id
}

\begin{abstract}
ABSTRAK
Desain penelitian ini bertujuan untuk mengembangkan model pembelajaran fisika berbasis masalah untuk meningkatkan keterampilan berpikir kritis dan proses sains mahasiswa pada materi Suhu dan Kalor. Metode penelitian ini (research and development) $\mathrm{R} \& \mathrm{D}$. Instrumen penelitian berupa tes keterampilan berpikir kritis berbentuk uraian. Intrumen keterampilan proses sains berbentuk pilihan ganda dan lembar observasi. Untuk merancang model pembelajaran Fisika berbasis masalah, analisis kebutuhan dilakukan melalui studi literatur dan studi lapangan, selanjutnya dilakukan validasi ahli dan uji coba terbatas untuk menyempurnakan draft model. Metode yang digunakan dalam penelitian ujicoba terbatas pra-eksperimental di Universitas Negeri Medan. Draft model yang telah direvisi berdasarkan hasil ujicoba terbatas, selanjutnya dilakukan ujicoba skala luas dengan metode kuasi-eksperimen di Universitas Negeri Medan dengan pretest-posttest control group design. Draft model yang telah disempurnakan berdasarkan hasil ujicoba skala luas, selanjutnya dilakukan diseminasi.
\end{abstract}

Kata Kunci: model pembelajaran berbasis masalah, keterampilan berpikir kritis, dan keterampilan proses sains

\section{PENDAHULUAN}

Fisika Umum merupakan ilmu pengetahuan tentang fenomena alam, berupa kumpulan fakta, konsep, prinsip, teori dan hukum serta proses yang sistematis untuk memperoleh konsep, prinsip, teori dan hukum yang kemudian dapat diuji kebenarannya. Fisika Umum mendasari fisika lanjut dan rekayasa yang berdasarkan hasil observasi fenomena, pengukuran yang tepat, interaksi yang luas dengan peralatan, eksperimen yang luas dan mendalam, serta interpretasi dan prediksi yang tepat.
Fisika Umum merupakan salah satu matakuliah wajib bagi mahasiswa calon guru fisika dan diberikan pada semester pertama. Selain dimensi isi, fisika juga memiliki dimensi proses dan sikap. Dilihat dari sisi proses, fisikawan menentukan variabel-variabel yang diteliti, dengan mengamati, bertanya, membuat hipotesis, memprediksi, menemukan pola dan hubungan, mengkomunikasikan, mendesain dan membuat, merencanakan dan melakukan penyelidikan serta mengukur dan menghitung. Kegiatan-kegiatan 
tersebut merupakan bagian dari keterampilan proses sains (Harlen \& Elstgeest, 1992; Karamustafaoğlu, 2011; dan Padilla, 1990). Dilihat dari sisi sikap, fisika sebagai bagian dari sains yang memberikan penghargaan terhadap nilai-nilai kemanusian (Rutherford \& Ahlgren, 1990).

Langkah-langkah
ditempuh peserta didik dari
pengamatan hingga melakukan penyelidikan lebih lanjut dan membuat kesimpulan, membentuk kemampuan berpikir analitis dan kombinatorial yang juga bersifat sintesis, karena itu pengalaman ini dapat mengembangkan keterampilan berpikir tinggi siswa, yaitu berpikir kritis dan pemecahan masalah.

Berpikir kritis merupakan serangkaian keterampilan kognitif dan disposisi intelektual yang diperlukan untuk mengidentifikasi, menganalisis dan mengevaluasi argumen secara efektif agar dapat menemukan dan mengatasi prasangka pribadi, dapat merumuskan dan menyajikan alasan yang meyakinkan dalam mendukung kesimpulan dan dapat membuat keputusan yang rasional dan tepat tentang apa yang dilakukan dan diyakini (Brookhart, 2010; Bassham et al., 2008; Moon, 2008; dan Ennis, 1987). Dengan demikian, keterampilan berpikir kritis merupakan kemampuan berpikir bagi seseorang dalam membuat keputusan yang dapat dipercaya dan bertanggung-jawab yang mempengaruhi hidup seseorang. Pentingnya pengembangan keterampilan berpikir kritis mahasiswa telah menjadi tujuan dari pendidikan pada akhir-akhir ini (Tsapartis \&
Zoller, 2003 dan Phillips \& Bond, 2004).

Pengembangan keterampilan berpikir kritis mahasiswa dimaksudkan untuk: (1) menyiapkan mahasiswa agar berhasil menghadapi kehidupan (Schafersman, 1991); (2) menciptakan penduduk yang memiliki kepedulian dan literasi terhadap lingkungan (Ernest \& Monroe, 2004); dan (3) meningkatkan kemampuan mahasiswa dalam menganalisis, mengkritisi, menyarankan ide-ide, memberi alasan secara induktif dan deduktif, serta untuk mencapai kesimpulan yang faktual berdasarkan pertimbanganpertimbangan rasional (Jones, 1996).

Bagi mahasiswa, keterampilan berpikir kritis diperlukan terutama untuk memahami konsep-konsep pada matakuliah yang sedang dipelajari. Dengan keterampilan berpikir kritis, mahasiswa akan dapat mengklarifikasi masalah, membuat kesimpulan dan interpretasi, serta mengevaluasi.

Mengingat

pentingnya keterampilan berpikir kritis, khususnya bagi mahasiswa calon guru fisika, keterampilan berpikir kritis hendaknya dikembangkan sejak dini (tahun pertama kuliah). Matakuliah Fisika Umum merupakan salah satu matakuliah wajib bagi mahasiswa calon guru fisika yang diprogramkan di tahun pertama kuliah karena matakuliah tersebut merupakan syarat untuk matakuliah selanjutnya. Karena matakuliah Fisika Umum sebagai fondasi untuk matakuliah fisika lanjut sehingga perlu ditangani secara sungguh-sungguh terutama untuk mengembangkan 
keterampilan berpikir kritis dan proses sains mahasiswa.

Salah satu model pembelajaran yang memberikan peluang bagi siswa untuk memiliki pengalaman menemukan suatu konsep dan mengembangkan keterampilan berpikir kritis dan proses sains adalah model pembelajaran berbasis masalah. Model pembelajaran berbasis masalah merupakan salah satu model yang membentuk mahasiswa melakukan pemecahan masalah secara kreatif, aktif dan menghargai keragaman yang timbul selama proses pemecahan masalah dengan kata lain model pembelajaran berbasis masalah merupakan model pembelajaran yang menggunakan masalah dunia nyata sebagai suatu konteks bagi mahasiswa untuk belajar tentang keterampilan pemecahan masalah, berpikir kritis dan proses sains untuk memperoleh pengetahuan dan konsep essensial.

Desain penelitian ini bertujuan untuk mengembangkan model pembelajaran fisika dengan pendekatan saintifik berbasis masalah untuk meningkatkan keterampilan berpikir kritis dan proses sains mahasiswa pada materi Suhu dan Kalor

\section{METODE PENELITIAN}

Penelitian ini menggunakan metode $\mathrm{R}$ and $\mathrm{D}$ melalui langkahlangkah 4-D, yaitu: pendefinisian (define), pendesainan (design), pengembangan (develop) dan diseminasi (disseminate) dengan penyesuaian seperlunya (Thiagarajan, et al., 1974).

Tahap pendefinisian dilakukan untuk menganalisis kebutuhan dengan mengumpulkan berbagai informasi yang berkaitan dengan produk yang akan dikembangkan. Pengumpulan berbagai informasi ini dilakukan dengan studi pendahuluan melalui studi literatur dan studi lapangan.

Tahap pendesainan dilakukan dengan merancang draft awal model yang dikembangkan dan perangkat pembelajaran untuk mendukung model pembelajaran Fisika Umum berbasis masalah pada materi Suhu dan Kalor, berupa (1) Pedoman pengelolaan pembelajaran;

Perancangan silabus berbasis masalah; (3) Perancangan LKM; (4) Perangkat tes, berupa: tes keterampilan berpikir kritis berbentuk uraian, tes keterampilan proses sains berbentuk pilihan ganda dan lembar observasi, angket, dan pedoman observasi.

\begin{tabular}{lrr}
\multicolumn{2}{c}{ Tahap } & pengembangan \\
dilakukan & dengan & memvalidasi \\
instrumen & dan & perangkat
\end{tabular}
pembelajaran kepada ahli, melakukan uji coba terbatas, ujicoba skala luas dan diseminasi model yang dikembangkan.

Data yang diperoleh pada penelitian ini terdiri atas data kualitatif dan data kuantitatif. Data kualitatif berupa: 1) karakteristik model pembelajaran berbasis masalah; 2) efektifitas model pembelajaran yang dikembangkan terhadap keterampilan berpikir kritis dan proses sains; 3) kekuatan dan kelemahan dalam mengimplementasikan model pembelajaran berbasis masalah; dan 4) tanggapan dosen dan mahasiswa terhadap model pembelajaran berbasis masalah yang dikembangkan.

Data penelitian ini terdiri dari data kuantitatif dan kualitatif. Data kuantitatif berupa skor tes keterampilan berpikir kritis dan 
proses sains mahasiswa. Data kualitatif dianalisis secara deskriptif interpretatif. Data kuantitatif dianalisis dengan menggunakan statistik inferensial.

\section{HASIL DAN PEMBAHASAN}

Analisis kebutuhan dilakukan melalui studi pendahuluan di Universitas Negeri Medan. Kegiatan ini dimaksudkan untuk mendapatkan gambaran tentang apa yang diperlukan mahasiwa sebagai calon guru fisika dan dapat dipenuhi melalui perkuliahan Fisika Umum, bagaimanakah kondisi perkuliahan Fisika Umum yang selama ini telah dilakukan, fasilitas belajar yang tersedia, serta latar belakang mahasiswa ditinjau dari keterampilan berpikir kritis dan proses sains.

Studi pendahuluan dilakukan dengan studi literatur dan studi lapangan. Melalui studi literatur dilakukan analisis terhadap kompetensi seorang guru fisika serta peran perkuliahan Fisika Umum, keterampilan berpikir kritis, keterampilan proses sains, teoriteori dan temuan-temuan penelitian. Studi lapangan dilakukan melalui observasi, wawancara, dan tes. Melalui observasi dan wawancara dapat dianalisis praktik perkuliahan Fisika Umum yang selama ini dilakukan dan fasilitas belajar yang tersedia. Analisis keterampilan berpikir kritis dan proses sains mahasiswa terhadap perkuliahan Fisika Sains digali melalui tes. Analisis kesulitan dan tanggapan mahasiswa terhadap perkuliahan Fisika Umum digali melalui wawancara.

Berdasarkan hasil pengamatan di lapangan, proses belajar mengajar di kelas cenderung dengan penurunan dan penerapan rumusrumus matematis. Mahasiswa berusaha menghapal rumus namun kurang memaknai untuk apa dan bagaimana rumus itu digunakan. Berkaitan dengan metode belajar, dari hasil wawancara dan observasi, dosen-dosen pengampu matakuliah Fisika Umum biasanya menggunakan metode ceramah dan tanya jawab dengan urutan menjelaskan, memberi contoh soal, bertanya, latihan, dan memberikan tugas. Alasan dosen menggunakan metode pembelajaran ini karena metode ini sangat mudah dilakukan untuk jumlah kelas yang besar dan materi ajar yang banyak. Beberapa dosen lain melaporkan bahwa mereka menggunakan model pembelajaran kooperatif dengan metode diskusi kelompok dan penugasan.

Masalah yang diberikan dosen berupa soal-soal yang ada di buku sumber yang lebih menekankan pada manipulasi matematis, bukan masalah konstektual yang ada dalam kehidupan sehari-hari. Mahasiswa yang lemah di bidang matematika akan sangat susah untuk dapat menyelesaikan soal tersebut.

Berdasarkan hasil wawancara, dosen belum pernah mengembangkan pembelajaran yang dapat meningkatkan keterampilan berpikir kritis dan proses sains secara khusus. Walaupun belum pernah membuat tes keterampilan berpikir kritis dan proses sains, tetapi dosen memandang perlu untuk membuat tes tersebut secara khusus.

Studi pendahuluan juga dilakukan terhadap sumber belajar dan fasilitas yang tersedia. 
Berkaitan dengan sumber belajar, umumnya mahasiswa menggunakan buku ajar (diktat) yang dibuat oleh tim dosen Fisika Umum sebagai sumber buku utama. Menurut mereka, buku ini merupakan buku pegangan dosen yang digunakan dalam perkuliahan, materinya diramu dari beberapa sumber. Selain buku ajar, mahasiswa juga memanfaatkan buku-buku teks yang tersedia di perpustakaan lembaga.

\section{Berdasarkan}

analisis kebutuhan mahasiswa, kondisi perkuliahan Fisika Umum, sumber belajar dan fasilitas, dan analisis kemampuan mahasiswa, maka salah satu tujuan yang hendak dicapai dalam perkuliahan Fisika Umum adalah meningkatkan keterampilan berpikir kritis dan keterampilan proses sains mahasiswa.

Indikator

berpikir kritis yang akan dikembangkan adalah mengklarifikasi masalah, membuat kesimpulan dan interpretasi, mendukung kesimpulan dan interpretasi, serta mengevaluasi (McLean, 2005). Indikator keterampilan poses yang akan dikembangkan adalah: mengobservasi, mengajukan pertanyaan, merumuskan hipotesis, memprediksi, merumuskan pola dan hubungan, berkomunikasi secara efektif, mendesain dan membuat, merencanakan dan melakukan penyelidikan, serta mengukur dan menghitung (Harlen \& Elstgeest, 1992).

\section{KESIMPULAN DAN SARAN}

Kesimpulan yang didapat berdasarkan hasil penelitian yang telah dilakukan adalah sebagai berikut:

1. Telah dirancang model pembelajaran Fisika Umum berbasis masalah untuk meningkatkan keterampilan berpikir kritis dan proses sains.

2. Indikator keterampilan berpikir krits yang dikembangkan adalah mengklarifikasi masalah, membuat kesimpulan dan interpretasi, mendukung kesimpulan dan interpretasi, serta mengevaluasi.

3. Indikator keterampilan poses yang akan dikembangkan adalah: mengobservasi, mengajukan pertanyaan, merumuskan hipotesis, memprediksi, merumuskan pola dan hubungan, berkomunikasi secara efektif, mendesain dan membuat, merencanakan dan melakukan penyelidikan, serta mengukur dan menghitung.

\section{UCAPAN TERIMA KASIH}

Terimakasih yang tulus disampaikan kepada Dirjen Pendidikan Tinggi yang telah memberikan dana untuk mendukung pelaksanaan penelitian hibah bersaing ini.

\section{DAFTAR PUSTAKA}

Bassham, G., Irwin, W., Nardene, H., \& Wallace, J.M. (2008) Critical Thinking: A Students' Introduction. $3^{\text {nd }}$ Edition. New York: McGraw-Hill Company, Inc.

Brookhart, S. M. (2010). How to Assess Higher order Thinking Skills in Your Classroom. ASCD. Alexandria, Virginia USA. 
Ennis, R. E. (1987). A Taxonomy of Critical Thinking Dispositions and Abilities in J. B. and R. J. Sternberd (eds). Teaching Thinking Skills: Theory and Practice. New York: W. H. Freeman and Company.

Ernest, J. \& Monroe, M. (2004). The Effects of Environment-Based Education on Students' Critical Thinking”. Environmental Education Research. 10(4), 507522.

Jones, D. (1996). Critical Thinking in an Online Word. [Online]. Tersedia:

http://www.library.ucsb.edu/un tangle/jones.html. [16 Oktober 1996].

Harlen, W \& Elstgeest, J. (1992), "UNESCO Source Book for Science Teaching in the Primary School', NBT, New Delhi.

Karamustafaoğlu, S. (2011). "Improving the Science Process Skills Ability of Science Student Teachers Using I Diagrams", Eurasian J. Phys. Chem. Educ. 3(1), 26-38.

McLean, C. L. (2005). Evaluating Critical Thinking Skills: Two Conceptualizations. Journal Of Distance Education Revue De L'éducation À Distance Spring/Printemps (20)2, 1-20.

Moon, J. (2008). Critical Thinking an Exploration of Theory and Practice. Routledge Taylor and Francis Group London and New York.

Padilla, M. J. (1990). The Science Process Skills, Research Matters-to the Science Teacher. No. 9004. [Online]. Tersedia di: http://www.narst.org/ publications/research/skill.cfm. [15 Februari 2014].
Philips, V. \& Bond, C. (2004) 'Undergraduates' Experiences of Critical Thinking". Higher Education Research and Development. 23(3), 277-294.

Rutherford, F. J. \& Ahlgren, A. (1990). Science for All Americans. New York: Oxford University Press.

Schafersman, S. D. (1991). Introduction to Critical Thinking. [Online]. Tersedia: http://www.freeinquiry.com/crit ical-thinking.html.

$[25$ September 2006].

Thiagarajan, S., Semmel, D. S. and Semmel, M. (1974). Instructional Development for Training Teachers of Exceptional Children. Source Book. Bloominton: Center for Innovation on Teaching the Handicapped.

Tsapartis, G. \& Zoller, U. (2003). "Evaluation og Higher vs. Lower-order Cognitive SkillsType Examination in Chemistry: Implications for University in-Class Assessment and Examination". U. Chem. Ed. 7, 50-57. 